\title{
ゴムダイスによる金属板の樑絞り 加工 (その 3)
}

\section{2 中立点の存在と加工能率の向上}

上記のように，ポンチなし深絞り法によると，きわめ て大きい絞り比の製品をえることができるが，絞り回数 をもらすこし少なくすること及び製品の形状・寸法をき れいに整えることができないかといらことが問題として 残る.

まず，ゴムリングを圧縮した際，素板の両面に作用す る摩擦力の関係を詳しく検討してみると, 正確には図 45 に示すようになっていることが知られる. すなわち，素 板上面の摩擦力は，すべて素板の移動を止めようとする が，下面では，ゴムリングと素板との移動速度が等しく なる点すなわち中立点 ${ }^{22)}$ を境として, 摩擦力の向きが逆 になる. そのために，図46に示すよ5な円周方向き裂を 生じることになる.（このような中立点の存在は,板材の 圧延や厚肉円筒の圧縮などの場合においても見られる.

そして，圧力分布にはいわゆる摩摖丘が現われ，分布は 一様でなく，中立点で極值を示す.)したがって，中立点 より外側にあって絞りの邪魔になる摩擦力が発生する部 分にまで，増摩剤を塗っておくことは，大変な損失であ るといえる. そこで, この点について検討するために， 一定 $(120 \mathrm{~mm})$ の素板径に対して, ロジン塗布径を変えて みると，図47のよらになる，また，加工能率がもっとも よいロジン塗布径 $90 \mathrm{~mm}$ で連続絞りを行らと，図48に示 すよ5に，絞り回数がほぼ半減した，同様の効果は，図 49からわかるように，ゴムリング径より素板径を小さく しておいた場合にもえられる.

\section{3 しごき加工による寸法精度の向上}

次に，図50は，製品の形状および寸法精度を整えるた め，ポンチなし絞り製品に，後加工としてしごき再絞り 加工を施した場合の製品例である. 一般に，ポンチなし 絞り製品の肉厚は，最初の素板板厚よりもむしろ増加す

\footnotetext{
*京都工芸絒維大学工芸学部生産機械工学科
} ( (606 京都市左京区松ヶ崎御所海道町 1)

\section{福田正 成*}

る傾向があるので，図51からわかるよらに，0 又はごく 小さいクリアランスで，しごきをかければよいことにな る.

\section{4 ポンチの併用}

最後に，ゴムリングを用いて絞る本法に剛体ポンチを 併用することができないかということは，本法が提案さ れた当初より考えられてきたことであった. しかし，ダ イス穴内にポンチを置くと，ゴムリングのダイス穴内へ の移動が妨げられるために，リング圧縮率がたかだか20 \%以下に制限され，素板に十分な絞り変形を与えること

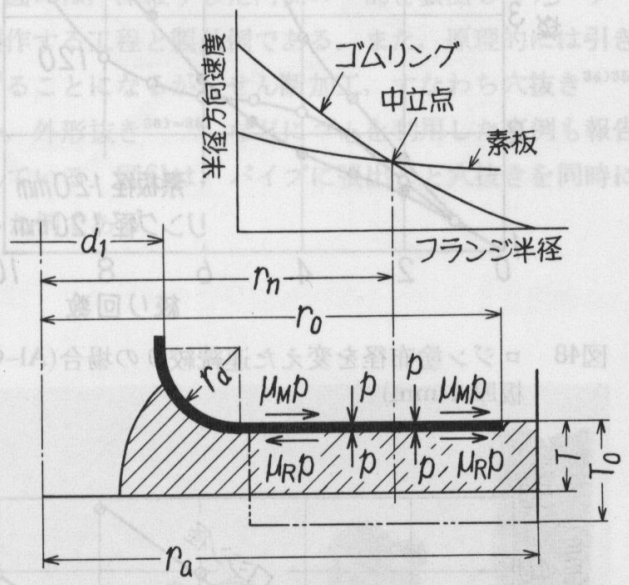

図45 ポンチなし深絞り機構の説明図

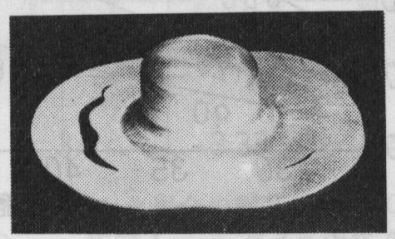

図46 フランジ部におけるる周方向き裂の例(Al-O) 


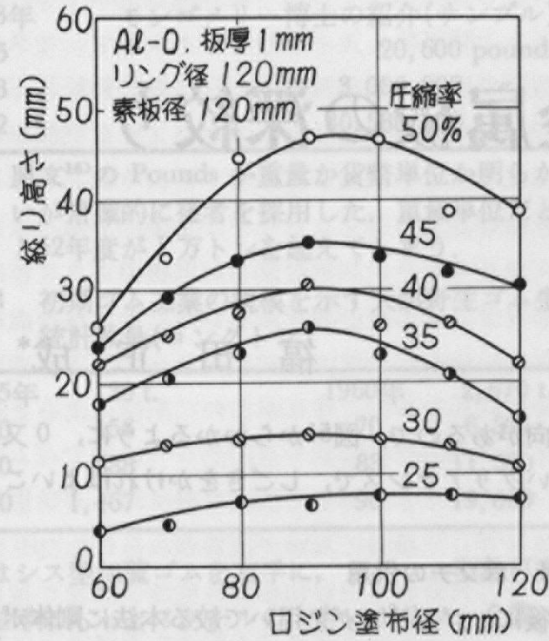

図47 ロジン塗布径を変えた 1 回絞りの場合

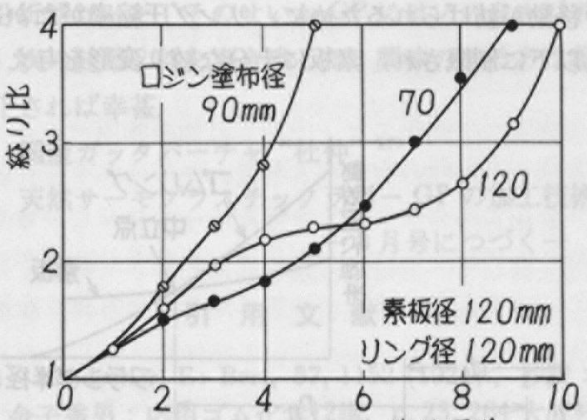

絞1)回数

図48ロジン塗布径を変えた連続絞りの場合 $(\mathrm{Al}-\mathrm{O}$, 板厚 $1 \mathrm{~mm}$ )

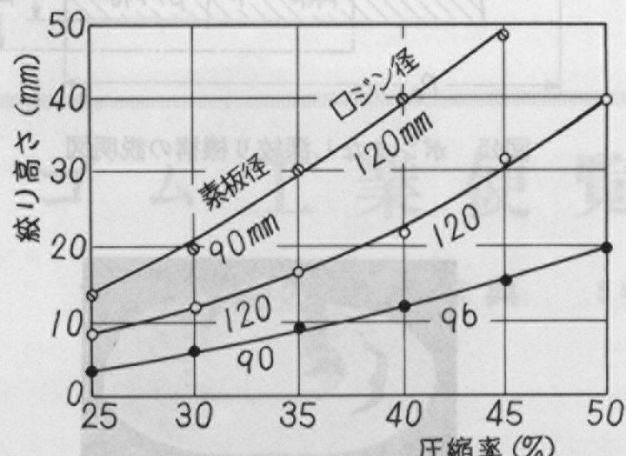

図49 素板径とリング径の比を変えた 場 合 (Al-O, 板厚 $1 \mathrm{~mm}$, ロジン全面塗布, 1 回絞り)

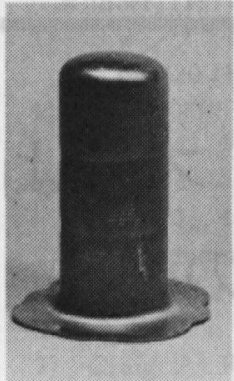

(a)加工前の製员 (絞1) 回数 4)

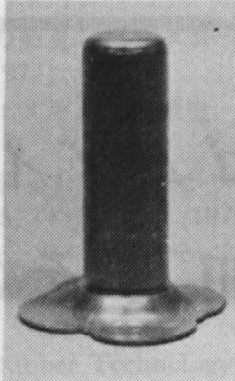

(b)

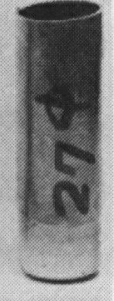

(C)
図50しごき再絞り製品例 (Al-O 板厚 $1 \mathrm{~mm}$ )

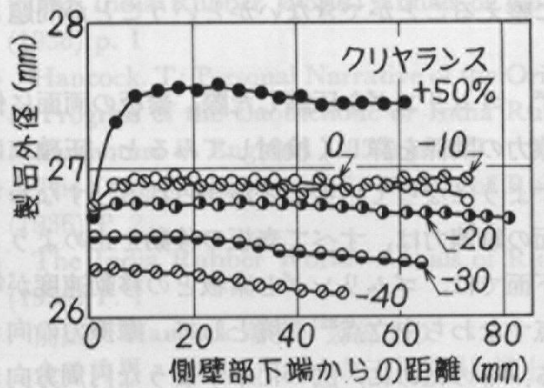

図51しごき両絞り製品の外径

ができない，また，ポンチで積極的に素板を絞りこもう としても，フランジ部に存在する大きな摩擦のために破 断が生じて不都合である。したがって，䇭者も，本法に ポンチを併用することの積極的意味は見出し難いと考え てきた. ところが,この䦗題 ${ }^{23)}$ は，図52に示すように， ダイスを 2 段にすることによって，ある程度の改善がで きるということを，最近になって確めることができた．

すなわち，下側のダイスの穴径を大きくして，ゴムリ ングに変形の余地を与えると，リング圧縮率が約 $30 \%$ ま で高められるので，素板を大きく絞りこむことができ る、そして, ある程度絞ってフラジ部が小さくなった段 階から以後は, 上側のダイスとポンチによって, 再絞り の形で絞りこんでしまうのである.このようにすると, ゴムリングによるフランジ部での摩擦力と，ポンチによ るけん引力とを同時に作用させなか゚ら，比較的少ない絞 り回数で，寸法精度の良好な製品をうることができるの である。

図53は，成形過程を示す。この場合の成形条件として 
成

は，まず，素板がポンチ肩部で破断しないように，ポン 千力 $\left(P_{\max } \doteqdot \pi d_{1} t_{0} \sigma_{B}, d_{1}\right.$ は再絞り直径, $t_{0}$ は素板板厚, $\sigma_{\boldsymbol{B}}$ は引張強さ) を設定する。 そして，下側ダイスと上側 ダイスとの穴径の比を，限界再絞り比に近い值に選ぶの が効果的である.

図54は，えられた製品例である。形状・寸法精度もよ く，表面あらさも $R_{a}=0.4 \mu$ 程度になっている。

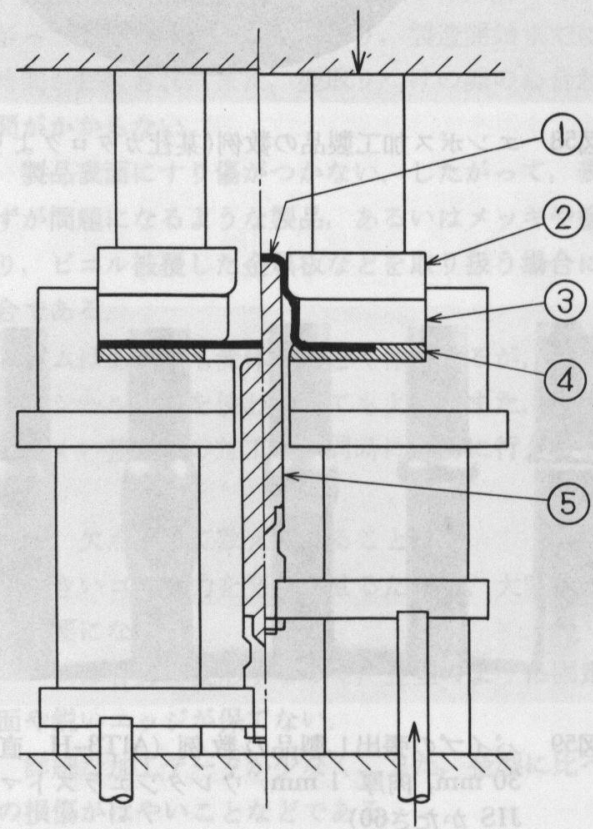

(1)素板 (2) 上側ダイス

(4)ウレタンリング

(3) 下側ダイス

(5) ポンチ

図52 ポンチを併用した装置の概略

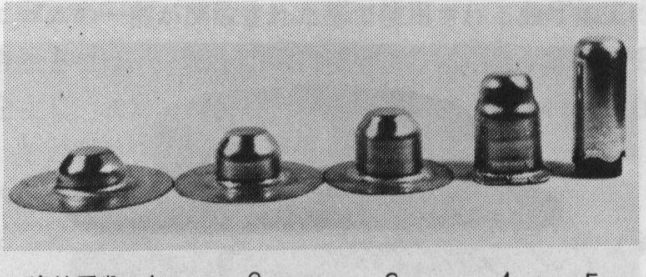

絞り回数 $=1$

2

3

45

図53 ポンチを併用した場合の成形過程 (Al-O, 素 板径 $100 \mathrm{~mm}$, 板厚 $1 \mathrm{~mm}$, ポンチ径 $26 \mathrm{~mm}$, $\left.r_{p}=5 \mathrm{~mm}\right)$

\section{6. ゴムを用いたその他の加工例}

以上， 3 回にわたり，主としてゴムを用いた深絞り加 工の場合の基本的な考え方ないしは成形過程と, それに よってどの程度の製品をえることができるかについて説 明してきたが，ゴムはこのほか，プレス加工のほとんど 全分野に対して利用することができる. 特に，1965年頃 より, ウレタンゴムが型材料として登場したことによっ て，その使用は一段と活発になった. やわらかい加硫ゴ ムは深絞り加工に，硬いウレタンゴムは曲げやエンボス 加工などに利用され，好成績をあげている. 以下，二， 三の使用例を紹介しよう。

図55は，ウレタンゴムダイスを用いたV曲げ24) 27) 及 びU曲げ28) 30)の場合であって, 補助工具(ロールバー)を 併用して，所要加工力の軽減をはかっている例である. 図56は，ロール曲げ31)の場合であり，図57はその製品例 である。 また网58は，エンボス加工による各種製品例で ある。

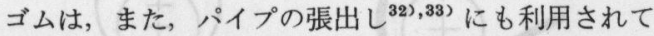
おりここ分野は，ゴムが大いに特色を発揮するもので あることはいらまでもなかろう。図59は，その一例であ り，図60は，深絞りした円筒の一部を張出してプーリー を製作する工程と製品例である，また，原理的には引き ちぎることになるが，せん断加工，すなわち穴抜き ${ }^{34) 35)}$

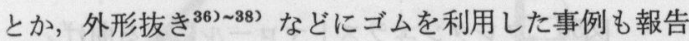
されている. 図61は，パイプに張出しと穴抜きを同時に 行った例である。

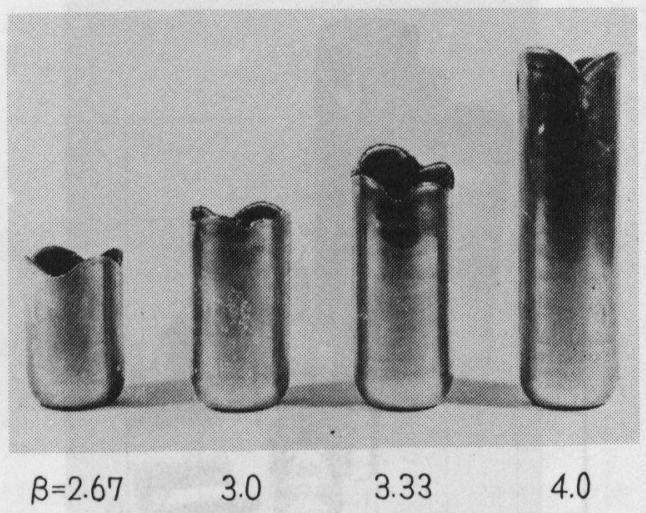

図54 ポンチを併用した場合の製品例 (Al-O, 素板 径 $120 \mathrm{~mm}$, 板厚 $1 \mathrm{~mm}$, ダイス穴径 $30 \mathrm{~mm}$, ポンチ径 $26 \mathrm{~mm}$ ) 


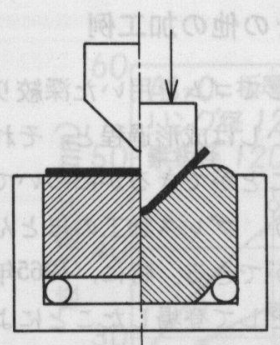

(a) V曲げの場合

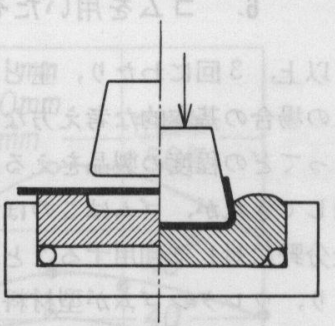

（b）U曲げの場合

図55 補助工具の使用と逃げを設けた型構造

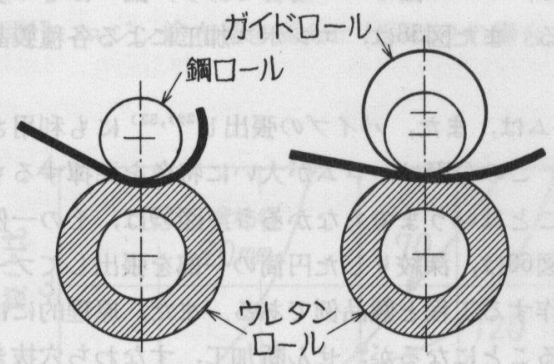

図56 ウレタンエラストマロールによる曲げ

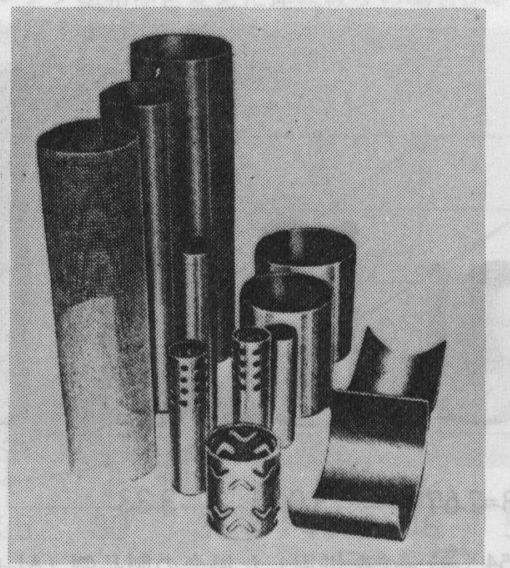

図57

ウレタンロールによる曲げ製品の数例（某社 カタログより)

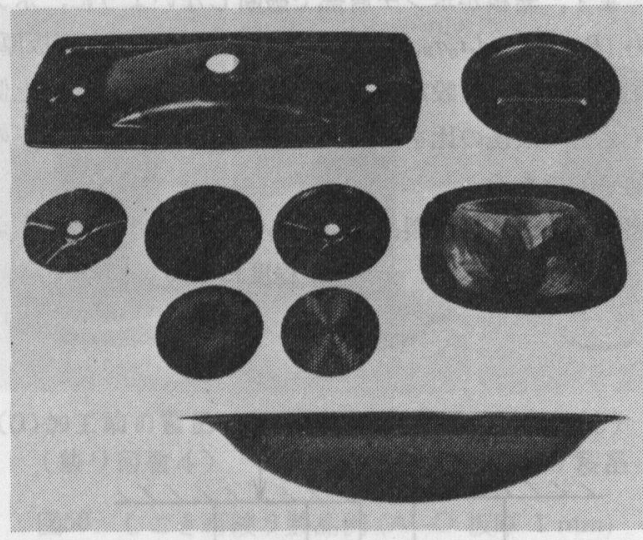

図58 エンボス加工製品の数例(某社カタログより)

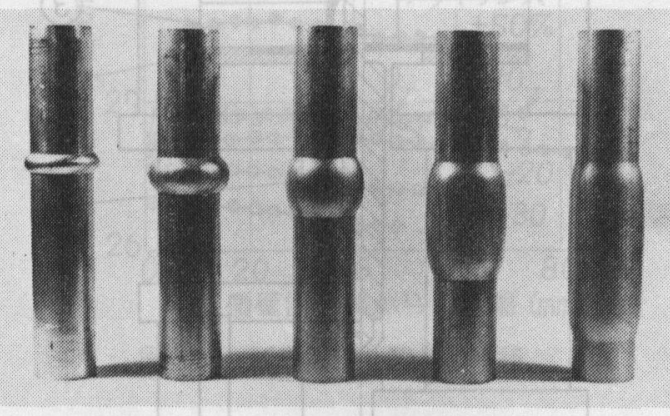

図59 パイプの張出し製品の数例（AIT3-H，直径 $30 \mathrm{~mm}$, 肉厚 $1 \mathrm{~mm}$, ウレタンエラストマ： JIS かたさ60)
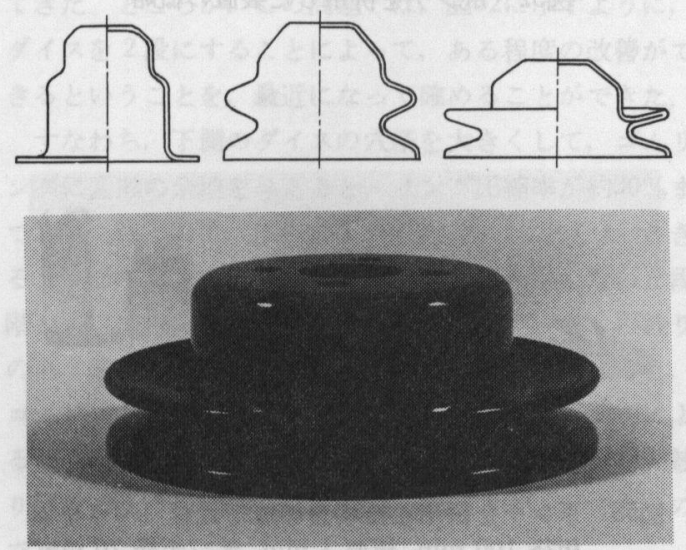

図60 Vプーリーの製作工程と製品例 


\section{7.あとがき}

最後に，本稿を終えるにあたり，一般にプレス加工の 分野で, ゴムを工具として使用する際に留意すべき二, 三の点について，付言しておこう。.

\section{1 ゴム工具の得失}

まず, ゴム工具のおもな利点をあげると，次のとおり である。

（1）金型の片方（たとえばポンチ）だけ作ればよく， ゴムダイスのほらはいわゆる万能型として共用できる。 したがって，型製作費が安価になり，製造開始までに必 要な時間が短縮され，また，型取りつけの際の心合わせ に手間がかからない.

（2）製品表面にすり傷がつかない，したがって，表面 のきずが問題になるような製品，あるいはメッキや塗装 したり，ビニル被覆した金属板などを取り扱う場合には 好都合である。

（3）ゴムはあたかも流体のごとく作動するが，液圧の 場合ほどシールに気を使わなくてもよい，また，金型で はできにくい整種類の加工を，同時に容易に行える場合 がある。

いっぽう，欠点として数えられることは，

(1) 大きいゴム圧力を発生させるために，大容量のプ レスが必要になる。

（2）ゴムは容易に変形するので，金型のように固定し た表面や鋭いエッジが保てない.

（3）詳細な加工データが少なく，また，金型に比べて ゴムの損傷がはやいことなどである.

\section{2 液圧成形法との比較}

つぎに，ゴムダイス法と類似の加工法に，よく知られ た液圧成形法 (ハイドロホーム，ゴム圧力のかわりに液 圧を用いる）がある。液圧の場合には，流体圧力がいた るところ均等にかかり，また，液体と素板との接触面に は摩擦が作用しない，ところが，ゴムを利用する場合， 特にゴムの一部が開放された形で使用される曲げ加工の 場合などでは，一例を図62に示すように，ゴム圧力に分 布を生じ，また，ゴムと素板の接触面には摩擦が存在 し，その摩擦係数を知ることが問題になる。

\section{3 加工条件の設定と製品精度の再現性}

ゴムは, 硬さ, 形状及び加工速度によって力学的な挙 動が異なるので, 成形に必要な加工力などを解析的に求 めようとすると，かなり面倒になる。したがって，ある 程度は試行錯誤的な手法によって見当をつけざるをえな いことが多い、しかし，素板の変形に注目すれば，ゴム

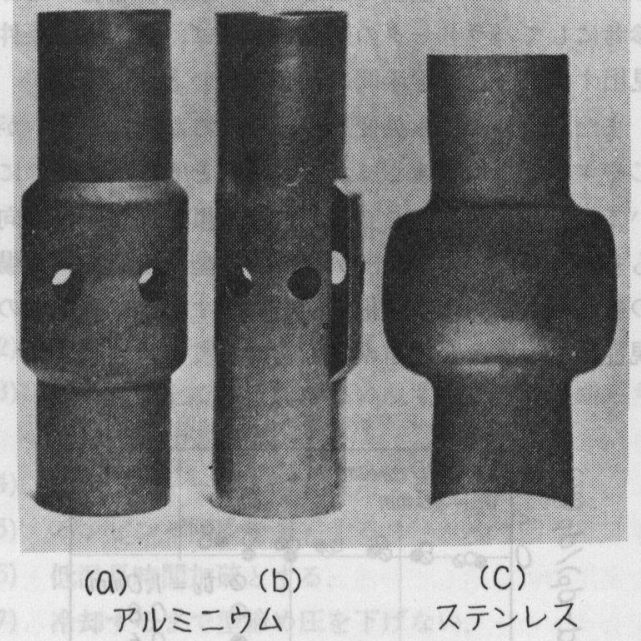

図61張出しと穴抜きを同時に行った場合の製品例 (Al-Qureshi, Mellor \& Garber)

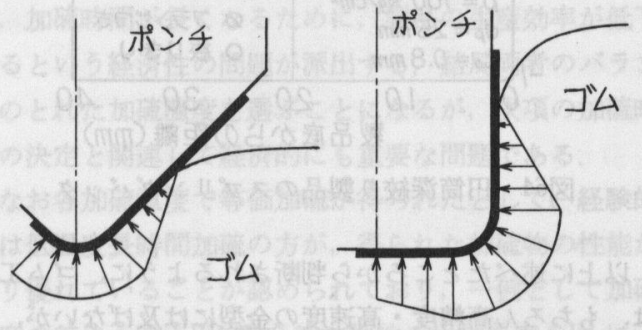

図62 V 曲げおよびU曲げの場合における近似的な ゴム圧力の分布

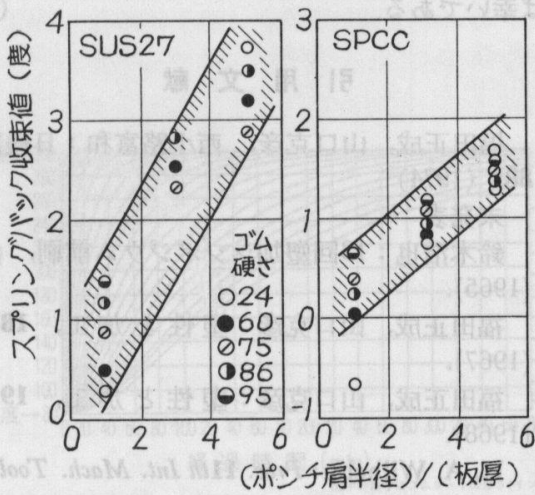

図63U曲げの場合のスプリングパック 
型でも金型の場合と根本的に大きい違いはないはずであ る.したがって, 金型によるプレス加工の場合の常識を 参考にしてパラメータの処理をすれば，最適加工条件を 見出すのに，さほど手間はかからないように思う。

また，ゴムには永久変形やいろいろな損傷 ${ }^{39), 40)}$ が生 じやすいことに関連して，製品精度とそのばらつきにつ いて，いささか取りこし苦労的な危惧をいだかれる向き も多いようであるが，一例を図63（型からはなれた場合 の製品の曲げ角度の変化), 図64に示すように, 結果の再 現性については，相当の自信を持ってよいと思う。

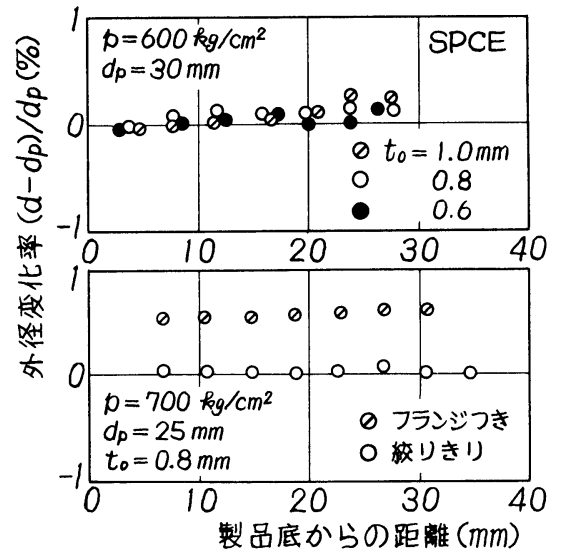

図64 円筒深絞り製品のスプリングバック

以上に述べたところから判断されるように，ゴム工具 は，もちろん高精度・高速度の金型には及ばないが，多 種少量生産を前提にした場合，加工対象によっては，ず いぶん偉力を発揮することが多いと思う。本稿が，ゴム 工具の特翼をご理解いただき，簡便なプレス加工用工具 としてゴムを利用していただく上に，少しでもご参考に なれば幸いである。

\section{引用文 献}

22）福田正成，山口克彦，西小路富和：日機論 40 885 (1974)

23）末発表

24）鈴木浩也：13回塑加シンポジウム前刷，p. 39 (1965).

25）福田正成，山口克彦：塑性と加工，18, 624 (1967).

26）福田正成，山口克彦：塑 性 と加工，19, 374 (1968).

27) H. A. Wilhelm: Proc. 11th Int. Mach. Tool Des. \& Res. Conf., p. 1019 (1970).

28) P. J. Mosedale: Sheet Metal Indust., p. 39
(1965).

29) 戸沢康寿, 川田勝巳 : 塑性と加工, 8, 367 (1967).

30) 福田正成, 藤本企 : 18回塑加連講論, p. 237 (1967).

31）小奈弘, 渡辺英世 : 塑性と加工, 18, 57(1977).

32) H. A. Al-Qureshi, P. B. Mellor, S. Garber: Proc. 9th Int. Mach. Tool. Des. \& Res. Conf., p. 319 (1968).

33）福田正成，伊東和彦：塑 性と 加工, 12, 112 (1971).

34) P. B. Hertz, S. Garber: Sheet Metal Indust., p. 761 (1964).

35）福田正成, 山口克彦：塑性と加工, 10, 53(1969).

36）宮川松男, 沖紘 : 塑性と加工, 7, 556 (1966).

37）中山邦彦：塑性と加工, 10, 288 (1969).

38) 杉田和弘：塑性と加工, 10, 295 (1969).

39）橘高重美, 佐藤金司, 宮隆一，宮木美光，佐野 達郎：塑性と加工, 17, 607 (1976).

40) 橘高重美, 佐藤金司, 宮隆一，宮木美光，佐野 達郎：塑性と加工, 17, 843 (1976).

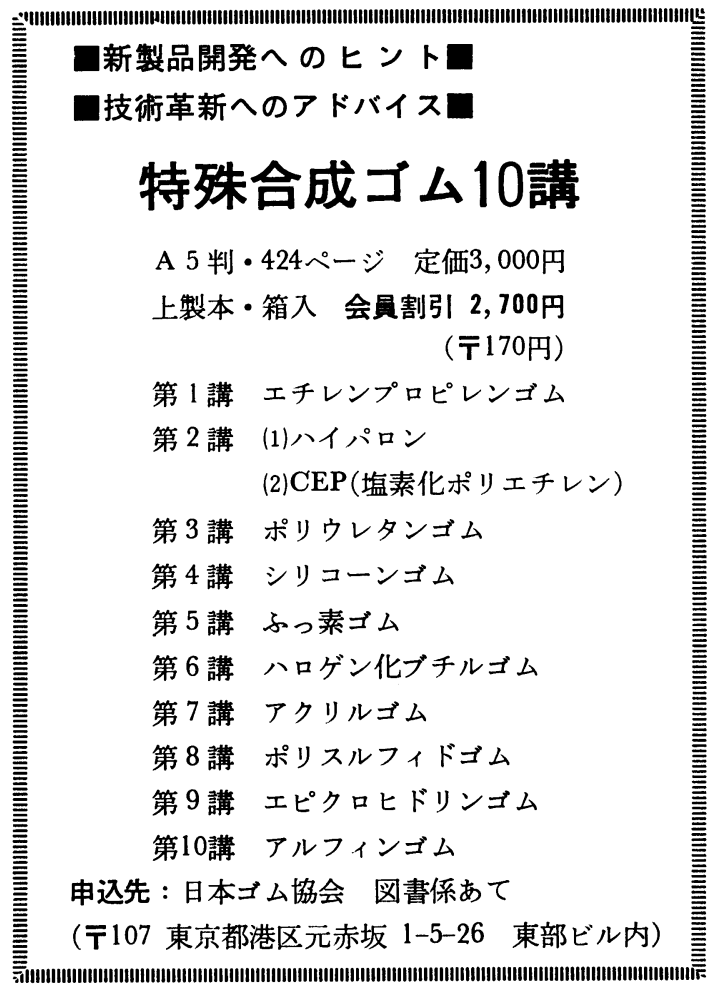

